\title{
Kultur og klasse - igen?
}

\section{Introduktion til Pierre Bourdieu}

Bourdieu er et navn, der høres med stigende frekvens i de universitære miljøer. Han er fransk sociolog, men har beskæftiget sig med så mange kulturelle emner, at han også kan have interesse for en del humanistiske fag. I denne artikel vil jeg derfor introducere nogle generelle teoretiske aspekter af hans tænkemåde, illustreret med nogle eksempler af egen opfindelse.

Som indledende bestemmelser kan man sige, at Bourdieus ambition er en kritisk kulturanalyse af forholdet mellem kultur og klasse. Hans metode er at foretage en videnskabelig, teoretisk konstruktion af de sociale spil som helhed - hvilket også inkluderer den position, som foretager konstruktionen - på grundlag af et omfattende empirisk materiale (såvel statistiske undersøgelser som interviews). Videnskabelighed, objektivitet og refleksivitet er derfor grundlæggende begreber i Bourdieus sociologi, som er dannet både med og mod Marx, Weber, strukturalisme, dekonstruktion og talrige andre sociologier og filosofier.

Hensigten med denne introduktion er at give læseren en forståelse af nogle nøglebegreber i Bourdieus måde at tænke sociologi på i hans mest kendte værk, La distinction. Critique sociale du jugement: ${ }^{1}$ relationel tænkning, habitus, felt, distinktion og smag. Derefter følger en skitse af et bourdieusk syn på de nyere samfundsudviklinger som eksempel på hans måde at tænke historie på, fulgt af nogle overvejelser over forholdet mellem videnskabelighed og refleksivitet. Som indledning til denne introduktion har jeg fundet det nødvendigt - fordi Bourdieus kontroversielle synspunkter altid støder på en vis modstand - at give et biografisk rids af Bourdieus karriere, samt en beskrivelse af de særegne vanskeligheder ved overhovedet at læse hans tekster.

\section{Biografisk}

Hvis det er værd at opholde sig ved Bourdieus biografi, er det, fordi den på flere måder belyser hans værker. Han blev født i 1930 i et fjernt hjørne af 
Frankrig, regionen Béarn i Sydvestfrankrig, som søn af en funktionær. Trods dette både sociale og geografiske lavklasse-udgangspunkt studerede han filosofi, matematik og videnskabsteori på eliteskolen École normale supérieure, bl.a. sammen med den jævnaldrende Derrida. Efter forskellige kortere universitetsstillinger, bl.a. i Algeriet, blev han i 1964 »directeur d'études« (hvad det end måtte betyde) ved en anden eliteskole, l'École pratique des hautes études. I 1981 overtog han så endelig Raymond Arons professorat i sociologi ved Collège de France, hvilket er omtrent så højt som man kan komme i den franske akademiske verden.

Bourdieu er altså en klar akademisk succes. Hans udgangspunkts beskedenhed betingede imidlertid en stor opmærksomhed over for forskellene mellem hans oprindelige erfaring af det sociale og hans senere bekendtskab med akademiske og kulturelle normer. Bortset fra hans første værker - nogle sociologiske bøger og artikler om Algeriet og nogle Lévi-Strauss-inspirerede etnologiske artikler om kabylerne (berberstamme i Atlasbjergene) og om ægteskabsritualer $\mathrm{i}$ hans hjemegn (efter hans eget udsagn den første applikation af etnologisk metode på indenlandske forhold) - handler hovedparten af hans produktion fra midten af 60 'erne og frem derfor om to emnekredse: uddannelsessytemet og kulturen og specielt forbindelsen mellem dem. Inden for disse emnekredse har han behandlet så forskellige emner som studerende, museer, fotografi, filosofi, sprog, sport, mad, mode og kunst, foruden emner som politik, økonomi og minoriteter, i sine talrige bøger og talløse artikler. I gennemsnit har han siden 60'erne udgivet knap en bog og ca. fem artikler om året, hvoraf en god del er udkommet $\mathrm{i}$ hans eget tidsskrift Actes de la recherche en sciences sociales (startet 1975), der ligesom hans bøger udgives af avantgardeforlaget Les Éditions du Minuit.

Efter Bourdieus eget udsagn er La distinction en opsummering af hans arbejde siden ca. 1965, og den er også hans mest ambitiøse og emnemæssigt mest omfattende bog: den handler om kunst-, kultur- og forbrugssmagens afhængighed af sociologiske faktorer. Andre senere bøger er Le sens pratique (1980), Ce que parler veut dire. Économie des échanges linguistiques (1982), Homo academicus (1984), L'ontologie politique de Martin Heidegger (1988) og La noblesse d'état. Grandes écoles et esprit de corps (1989). En mindre, men væsentlig bog til forståelse af hans teoretiske standpunkt er hans tiltrædelsesforelæsning ved Collège de France, Leçon sur la leçon (1982), som jeg også vil referere til i det følgende. De fleste af Bourdieus bøger er oversat til engelsk og andre sprog. 


\section{Vanskeligheden ved at lase Bourdieu}

Når jeg her vil gengive de fem stadier, som min læsning og forståelse af $L a$ distinction måtte gennemgå, før jeg endelig forstod, hvad han mente, skyldes det, at andre læsere tilsyneladende har haft de samme vanskeligheder - at dømme efter spørgsmålene og svarene i de mange interviews, der er genoptrykt i Bourdieus Questions de sociologie (1980/88) og Choses dites (1987), der også rummer nogle af hans forelæsninger. ${ }^{2}$

I det første stadium er der tale om et rent og skært forståelsesproblem: Bourdieus lange sætninger med talrige indskud, præciseringer og kvalifikationer er simpelthen svære at forstå. Det ligner nærmest en karikatur af tysk filosofisk sprogbrugs værste sider og må ofte læses og udlægges, som var det latin. Bogen er heller ikke alt for klart struktureret, fordi den både er teoretisk og empirisk og derfor ikke har en begrebsudviklings eller en rent empirisk redegørelses klare forløb. Dertil kommer, at der blandt bogens righoldige statistiske materiale forekommer nogle faktorielle analyser, hvis virkemåde og mening overhovedet ikke forklares; en fodnote henviser til to værker om statistisk teori.

Når man dernæst har forstået, hvad der står, - i hvert fald noget af det gribes man så af ophidselse, særligt hvis man som jeg indgår i det litteraturvidenskabelige felt eller beslægtede felter: Bourdieu hævder f.eks., at kunsten er forudbestemt til at fungere som en legitimation af social forskel, fordi $\gg$ distinktionsforholdet er objektivt indskrevet i den« (s.249), f.eks. i litteraturen som en anden, d.v.s. forskelssættende måde at bruge sproget på, og han tillader sig det barbariske spørgsmål om hvilken interesse den desinteresserede kunstbetragtning tjener. - Hvad! Skal det nu være socialt undertrykkende at læse bøger!? tænker man, grebet af sit felts interesse og enøjethed. I dette andet stadium gør man modstand mod Bourdieus objektivering og reproducerer dermed med stor sikkerhed og mange subtile argumenter præcis den interesserede position, som Bourdieu møjsommeligt prøver at give en objektiv beskrivelse af. Det var i hvert fald min skæbne i denne artikels første version.

I tredje stadium går det så op for én - bla. ved lasning af interviews i de to ovennævnte bøger, hvor Bourdieu bliver tvunget til at forklare sig nærmere at Bourdieu mener det alvorligt med refleksiviteten, som annonceres på bogens første sider. Med refleksivitet menes, at Bourdieu i sin objektivering af det sociale system og dets forhold til livsstilens eller smagens system også vil medtænke »det synspunkt, fra hvilken den [objektiveringen] udsiges« (s.10) og altså foretage »en konstruktion af spillet som helhed « (ibid.). Eller som han siger om sociologien: »Alle de udsagn, som denne videnskab udsiger, kan og må appliceres på det subjekt, som praktiserer denne videnskab ${ }^{3}{ }^{3}$ Denne re- 
fleksivitet forbliver implicit i La distinction, men når man har indset, at den er der, indser man også, at beskrivelserne ikke er normative, d.v.s. ment som aggression eller fordømmelse af kulturen eller akademikere eller noget tredje.

Med denne indsigt træder man ind i det fjerde stadium, hvor man kan genlæse bogen som deskriptiv i stedet for normativ. Når det er svært at se, at beskrivelserne af sammenhængen mellem livsbetingelser og smag er så neutrale og objektive som muligt, hænger det sammen med sprogets sociale ladning. Hvis Bourdieu f.eks. anvender modsætninger som fin/grov, let/tung, sublim/ vulgær, distingveret/banal, raffineret/rå etc. til at beskrive aspekter af forholdet mellem den socialt høje og den socialt lave kultur, så ligger der intet normativt i det, han bruger blot de termer, som den socialt høje position objektiverer den lave med. Dermed kan Bourdieu ikke alene objektivere relationen mellem de to sociale positioner, givet ved den højeres afvisning af den lavere, men også det sociale sprog, som afvisningen foregår i. På den måde laver Bourdieu ofte en slags montage af en sprogbrug svarende til en social position (f.eks. et modsætninssystem eller et ordforråd), der på én gang udpeger den sociale relation (f.eks. modsætningen finkultur/massekultur), som sprogbrugen etablerer, og relationens konstituering i denne sprogbrug (modsætningen finkultur/ massekultur er selvsagt udsagt fra finkulturens position). Konstruktionen af den objektive relation er altså resultatet af en proces, der går fra den interesserede objektivering af den ene position over udpegningen af det interesserede sprog til objektiveringen af begge positioner; vanskeligheden ved at læse Bourdieu er, at alle disse tre niveauer ofte findes i én og samme sætning.

Når man således har gennemgået denne vanskelige skoling $\mathrm{i}$ at læse Bourdieu, kan man træde ind $i$ forståelsens femte stadium, hvor man (i hvert fald jeg) accepterer Bourdieus udsagn, accepterer f.eks. at kultur- og kunstkendskab faktisk sætter forskelle, der kun kan betegnes som sociale, eftersom disse forskelle altid optræder i forhold mellem mennesker og eftersom muligheden for at sætte dem afhænger - statistisk set - af sociologisk beskrivelige faktorer som uddannelse og social herkomst. Og man erkender, at disse forskelle ikke behøver at være særligt dramatiske eller voldsomt undertrykkende. I dette stadium mister man også interessen for at kritisere Bourdieu og søger i stedet at forstå, hvad han mener, for at se om det skulle kunne bruges til noget. Under alle omstændigheder er kritik vanskelig, fordi Bourdieu af angst for at blive mislæst på forhånd synes at have taget højde for alle tænkelige indvendinger; hans position er som en en fæstning med så subtile forsvarsværker, at angriberen oftest ender med at opdage, at han har indtaget sin egen lejr.

En yderligere vanskelighed ved at læse Bourdieu - og særligt La distinction - er vanskeligheden ved at placere ham i det intellektuelle felt. Ikke kun fordi han ofte bruger henkastede citater (»som Leibniz siger...«) uden kildehenvis- 
ning, men også fordi det simpelthen er svært at se, hvilken filosofisk eller sociologisk tradition han indgår i. I La distinction nævner han således stort set kun sine forgængere for at kritisere dem. Forklaringen synes at være, at han ofte på én gang tænker med og mod sine forgængere, f.eks. ved at applicere deres egne teorier på dem selv eller ved at nuancere dem v.h.a. begreber hentet fra andre tænkere. Det er således ikke muligt at sige om Bourdieu, at han er entydigt for eller imod Marx, Weber, Durkheim, Sartre, Lévi-Strauss, Foucault, Althusser, Derrida, psykoanalysen, Frankfurterskolen ${ }^{4}$ eller hvem man ellers kunne nævne; at hans belæsthed er kolossal er derimod sikkert. Som han siger $i$ et interview har han et pragmatisk forhold til de overleverede mestre, hvis værker han betragter som »en slags næsten uudtømmelig værktøjskasse $\ll .^{5}$ Man genfinder derfor ofte dette eller hint begreb eller synspunkt fra en af hans forgængere $i$ hans tekster, men altså uden at man deraf kan slutte, at han er marxist eller satrianer eller noget tredje. I hvert fald er det ikke dette aspekt, jeg vil skrive om i det følgende.

\section{Nogle nøglebegreber}

Et af de vigtigste grundlag for Bourdieus måde at tænke på er en slags strukturalisme, der dog lige så meget er inspireret af naturvidenskabelige metoder som af Saussure eller Lévi-Strauss, og som til en vis grad også kan forstås som en kritik af deres form for strukturalisme: »Det vigtigste bidrag fra det, som må kaldes den strukturalistiske revolution, består i at applicere en relationel tænkemåde på det sociale, - en tænkemåde, som er den man finder i moderne fysik og matematik, og som identificerer det virkelige med relationer og ikke substanser «. ${ }^{6}$ Modsætningen mellem relation og substans er overordentligt vigtig hos Bourdieu; det drejer sig ikke om at definere f.eks. fattigdom som en substantiel egenskab ved en given klasse, men om at definere den relation, der udpeger en fattig og en rig position. Kun ved at tænke relationelt og ikke substantielt kan man nå til en objektivering, der ikke fordrejes af at være set fra den objektiverendes position.

Denne relationelle tænkning fører bort fra modstillingen af individ og samfund som et subjekt/objekt-forhold (hvor enten subjektet kan ses som subjekt for sine handlinger i forhold til samfundet som objekt, eller subjektet er objekt* for samfundets eller systemets determination). I stedet for at se samfundsforholdene som ting eller tilstande, eksemplificeret ved sætninger som »han har magt«, hvor magten optræder som en substans knyttet til et individ (evt. system), ser Bourdieu på relationer og processer; for først da kan man se, at subjektets handlinger på den ene side er bestemt af dets internalisering af objek- 
tive strukturer, og at subjektets handlinger på den anden side også kan bidrage til at ændre de objektive strukturer.

I Bourdieus terminologi er der tale om mødet mellem en agents habitus og et felt. En agents habitus bestemmes af en række sociologiske faktorer som social herkomst (målt ved faderens profession), uddannelse, indkomst og formue, profession, alder, $k \emptyset n$ mv., der internaliseres og danner grundlaget for agentens handlinger og bedømmelse af andres handlinger i feltet. Habitus defineres derfor som at gøre dyd af den nødvendighed, der ligger i agentens objektive livsbetingelser, og selv om en habitus i sidste instans er individuel, kan der alligevel konstrueres klasser af habitus-typer. Eksempelvis vil man næppe tænke på at købe bil eller hus, hvis man tjener under 100.000 om året; eller man vil næppe tænke på at læse Joyce eller se Wozzeck, hvis man kun har folkeskolens afgangsprøve, arbejder i et ikke-bogligt fag og ikke har en kulturelt interesseret omgangskreds; hvis man er akademiker, vil man næppe se Lykkehjulet, og hvis man tjener en million om året, vil man næppe købe tøj i Daells Varehus, - ja, de pågældende agenter vil i reglen end ikke have lyst til disse handlinger (jeg må hellere understrege, at der i disse forhold ikke er tale om determination som entydig kausalitet, men som statistisk sandsynlighed, d.v.s. om det typiske).

Et felt (champ) er et område for en specifik menneskelig aktivitet, der fordrer en specifik kompetence af agenterne. Eksempelvis taler Bourdieu om feltet for kulturel produktion og feltet for kulturelt forbrug. Førstnævnte kan opdeles i felter for produktion af litteratur, maleri, skulptur, musik, teater, dans etc., og litteraturfeltet kan videre opdeles i felter for produktion af poesi, romaner, drama, noveller o.s.v. i det uendelige. En mere præcis definition af felt er vanskelig at give; minimumsbetingelsen kunne være, at mindst to agenter er enige om at være uenige. Det kan selvfølgelig også forekomme, at agenterne er enige om at være enige, men i så fald har feltet en tendens til at forsvinde, fordi det mangler en fornyende egendynamik.

Alle felter er imidlertid grundlæggende struktureret på samme måde, over homologe relationer. Paradigmet for denne struktur er strukturen i det sociale rum (espace social), d.v.s. den teoretiske konstruktion af totaliteten af de relationer, som forskellene på klassernes og klassefraktioners livsbetingelser danner. Eller med andre ord: et skema over klassernes indbyrdes placering. Til konstruktionen af det sociale rum anvender Bourdieu en $\varnothing$ konomisk terminologi. Eksempelvis er en bestået eksamen en uddannelsesmæssig kapital, som man kan profitere af på et marked (= felt). På samme måde er kendskab til kunst en kulturel kapital og den sociale herkomst en social kapital (social kapital betegner dog også ens netværk af forbindelser og bekendtskaber). Hertil kommer naturligvis den egentlige kapital, altså indkomst, formue, frynsegoder 
etc. En klasses placering i det sociale rum afhænger så af dens position i forhold til tre akser: (1) mangden (volume) af samlet kapital, primært $\emptyset$ konomisk kapital og kulturel kapital, hvor den kulturelle kapital primært afhænger af den uddannelsesmæssige kapital og sekundært af den sociale herkomst, ${ }^{7}$ (2) den samlede kapitals struktur, d.v.s. forholdet mellem mængden af økonomisk hhv. kulturel kapital, (3) den tidslige (eller historiske) udvikling i mængden og strukturen af kapitalen, d.v.s. en given klasse eller klassefraktions stigende eller faldende bane (trajectoire) i fortid eller fremtid og i forhold til de andre klasser eller klassefraktioner. Eksempelvis folkeskolelæreres faldende bane i forhold til andre klassefraktioner: p.g.a. den generelt stigende uddannelsesgrad mindskes den relative betydning af deres kulturelle (uddannelsesmæssige) kapital og dermed også af deres økonomiske kapital (indkomst). Af praktiske grunde (papirs to-dimensionalitet) kan Bourdieus skema (s.140-41) over det sociale rum kun gengive de to første akser; jeg har konstrueret en stærkt forsimplet model, der indbefatter de tre positioner, hvis relationer - specielt i forhold til det kulturelle felt - Bourdieu behandler mest indgående:

mængde af kapital +

$\begin{array}{llll}\text { kulturel } & \text { intellektuelle } & \text { arbejdsgivere } & \text { kulturel } \\ \text { kapital }+ & \text { universitetsfolk } & \text { i industri og handel: } & \text { kapital } \div \\ \text { økonomisk } & \text { kunstnere: domineret } & \text { dominerende } & \emptyset \text { kono- } \\ \text { kapital } \div & \text { fraktion af dominerende } & \text { fraktion af dominerende } & \text { misk } \\ & \text { klasse } & \text { klasse } & \text { kapital + }\end{array}$

arbejdere, landarbejdere, kassedamer:

domineret klasse

mængde af kapital :

Hertil et antal kommentarer. For det første betyder »classe dominante « naturligvis »herskende klasse«, men for dels at undgå en alt for automatisk afvis ning af denne teoretiske konstruktion som gammelmarxistisk pladder, dels for at tydeliggøre, at de intellektuelle er en del af den herskende klasse for så vidt som de udøver en kulturel dominans, har jeg valgt at oversætte det med dominerende klasse, - også for at understrege, at der i ordet dominans er mere spillerum for en udfordring af dominansen (i kulturel henseende f.eks. i rindalis- 
men) end i mere entydige og negativt ladede ord som magt eller herredømme.

For det andet rummer Bourdieus skema naturligvis et mylder af andre klasser og fraktioner: et langstrakt hierarki af funktionærer fra kassedamer og butiksekspedienter over underordnet kontorpersonale og mellemledere til ansatte ledere i det offentlige og i det private erhvervsliv. Et hierarki af undervisere fra folkeskolelærere over gymnasielærere til universitetsprofessorer. Et hierarki af selvstændige arbejdsgivere fra detailhandlere og håndværksmestre til de af industriens og storhandlens ledere, der selv ejer deres virksomheder; desuden liberale erhverv, kulturformidlere, landmænd, ingeniører, et hierarki af arbejdere (ufaglærte, specialarbejdere, faglærte arbejdere, værkførere) o.s.v., - klasser og klassefraktioner, der defineres ved deres relative forskelle m.h.t. mængde og struktur af kulturel og økonomisk kapital.

For det tredje er de tre positioner i mit forsimplede skema defineret som det sociale rums ekstremer: de intellektuelle har den højeste kulturelle kapital og relativt lav $\emptyset$ konomisk kapital, mens arbejdsgiverne af den traditionelle ejertype har den højeste økonomiske kapital og en relativt lav kulturel kapital, og arbejdere er defineret som det relative nulpunkt for kapital overhovedet (posedamer og clochards, som kunne siges at være et absolut nulpunkt, kan måske netop defineres ved at være faldet ud af det sociale rum). Almindeligvis definerer klassefraktionerne sig selv i forhold til de nærmestliggende klassefraktioner (f.eks. universitetslærere i forhold til gymnasielærere).

For det fjerde: klasser eller klassefraktioner defineres altså som en gruppe agenter med homogen kapitalmængde og -struktur, men disse primære faktorer nuanceres af sekundære faktorer som alder, køn, gift/ugift, børn/ikke børn, bopæl, race (sidstnævnte er ikke så relevant i Danmark - endnu). Både primære og sekundære faktorer er indbyrdes afhængige, hvilket vil sige, at den sociale position og den kulturelle praksis determineres af strukturen i forholdet mellem dem. Vil man altså analysere kulturforbruget i en given klassefraktion, f.eks. sekretærer med korrespondentuddannelse, må man også medtænke den strukturelle relation mellem de andre faktorer: en ugift, mandlig sekretær på 25 år, bosat på Østerbro, vil således med stor sandsynlighed have et andet kulturforbrug (livsstil) - og en anden fremtidig karriere - end en 40-årig, gift, kvindelig sekretær med to børn, bosat i Greve; omend videre forskelle kunne afhænge af f.eks. ægtefællens herkomst, uddannelse og profession, af de to agenters sociale herkomst og af arbejdspladsens art (stor/lille, ekspanderende/ på vej ned, dens fagområde etc.). Som man ser er der mulighed for betragtelige kompleksiteter og endeløse differentieringer.

For det femte er Bourdieus skema præget af, at hans statistiske materiale er fra 60'erne og 70'erne. Kapitalismens stigende anonymisering og internationalisering har medført en mindskelse af klassen af arbejdsgivere, der selv ejer 
deres virksomheder - omend denne proces langtfra er fuldført. Den dominerende fraktion af den dominerende klasse vil derfor i dag snarere bestå af ledere $\mathrm{i}$ administration og $\emptyset$ konomi med tilsvarende uddannelser, og modsætningen mellem klassefraktionerne med hhv. høj kulturel kapital og høj økonomisk kapital vil derfor tendentielt blive erstattet af »modsætningen mellem den intellektuelles interesseløse, uvirkelige og urealistiske kultur og de »moderne lederes« $\emptyset$ konomiske og polytekniske kultur, der opfatter sig som handlingsrettet uden at være reduktibel til uværdigheden i en simpel »praksis«« (s.361).

Alle felter er som sagt struktureret over det sociale rums paradigme; de organiseres efter samme logik og struktureres af homologe modsætninger, som man ser af denne passage, der også kan tjene som eksempel på Bourdieus stil:

»alle specialiserede felter (feltet for haute couture eller for maleri, for teater eller for litteratur) har tendens til at organisere sig efter samme logik, d.v.s. efter mængden af agenternes specifikke kapital (og efter deres ofte dermed forbundne anciennitet i feltet), og [...] modsætningerne, som har tendens til at blive etableret mellem de mest rige og de mindst rige på specifik kapital, mellem de dominerende og de dominerede, mellem forsvarerne og angriberne, de ældre og de nyligt indtrædende, distinktion og prætention, ortodoksi og kætteri, bagtrop og avantgarde, orden og bevægelse, etc., er indbyrdes homologe (heraf allehånde invarianter) og homologe til de modsatninger, der organiserer de sociale klassers felt (mellem dominerende og dominerede) eller til den dominerende klasses felt (mellem den dominerende og den dominerede fraktion)« (s.257).

Et felt er altså for det første defineret af de forskelsrelationer, som forskellene på mængden af agenternes specifikke kapital danner (eksempelvis i en faglig diskussion mellem en lærer og en elev), og for det andet ved at disse forskelsrelationer er homologe til dominansrelationerne i det sociale rum (stor kapitalmængde giver en dominerende position). De specialiserede felter har dog en relativ autonomi i forhold til det sociale rum, fordi de har en specifik logik og fordrer en specifik kapitaltype: akademisk succes kan ikke købes for penge, men kun ved investering af arbejde, der må overholde det akademiske felts logik eller kode. Men agenternes indsats på feltet adlyder sædvanligvis det samme generelle $\varnothing$ konomiske princip, nemlig »ratio i betydningen beregning af det optimale, som gør at man kan rationalisere en hvilken som helst adfærd « ${ }^{8}$

Agentens forhold til feltet er som tidligere nævnt dobbelt: for at kunne agere på feltet må agenten i første omgang internalisere feltets regler, men deref- 
ter kan agenten også forsøge at ændre på feltets dominansrelationer eller objektive strukturer. Det forudsætter naturligvis, at agenten har en interesse $\mathrm{i}$ feltet, d.v.s. investerer (f.eks. sin tid) i det. Man kan altså ikke gøre hvad som helst $\mathrm{i}$ en given tilstand af et felt, men for så vidt som man ved sin investering i feltet har opbygget en kapital, hvis art og mængde anerkendes af feltets $\emptyset \mathrm{v}-$ rige agenter - eller nogle af dem - kan man forsøge at ændre på feltets regler, således at man kan gøre noget andet, evt. tilrane sig den dominerende position. Et felts dynamik er således givet ved en kamp eller konkurrence (eller, i en mere fredelig metaforik, et spil, en leg) om den dominerende position, d.v.s. den position der etablerer den legitime definition af feltets regler, herunder dets grænser (man kan f.eks. tænke på striden mellem knækprosa-lyrikere og '80er-lyrikere i begyndelsen af ' $80 \mathrm{erne}$, i høj grad en strid om definitionen af legitim lyrik).

Denne dynamiske konkurrence om feltets dominansposition er en konkurrence om distinktion, der selvfølgelig er et hovedbegreb i La distinction. Distinktion eller distingverethed er en hierarkisk forskel, og den fungerer kun, hvis den finder de domineredes anerkendelse (at køre i Rolls Royce er distingveret for så vidt som det anerkendes som sådan af dem, der ikke har råd til det). Den anerkendte distinktion er imidlertid ikke resultatet af en søgen efter distinktion som sådan: det ville være prætention, som f.eks. i kulturel henseende er et træk ved de mellemlag, som er defineret ved at have nogen, men ikke maksimal kapital. Dialektikken mellem prætention og distinktion er ofte princippet for udviklingerne $i$ et felt: når en given ting, der har fungeret som distinktionstegn i forbrugsfeltet, bliver for udbredt ved at de lavere klasser tilegner sig den og dermed prætenderer at være en højere klasse, må den højere klasse finde nye ting at give tegn med. Det er ofte en ubevidst proces, der ytrer sig som en lyst til at prøve noget nyt, d.v.s. noget andet, en forskel, og denne lyst kan give paradoksale resultater: hvis en lavere klasse overtager en højere klasses spektakulære livsstil (ofte kun delvis p.g.a. manglende midler, eksempelvis m.h.t. til t $\not \mathbf{j}$, men ikke bil eller bolig), kan den højere klasse enten forny sin distinktion ved at anskaffe de nyeste, mere spektakulære produkter, som feltet for produktion af forbrugsgoder tilbyder, eller ved at anlægge en spektakulært ikke-spektakulær livsstil (fordi det er blevet prætentiøst, for ikke at sige vulgært at distingvere sig efter feltets tidligere tilstand). Udviklingen på overordentligt mange felter kan beskrives på denne måde, også aspekter af akademisk og kunstnerisk distinktion; en faktor i fornyelsen er ofte konkurrencen mellem generationer, som konkurrerer om at påtvinge de andre definitionen af legitim distinktion: eksempelvis yuppiernes konkurrence med ældre generationer af samme klassefraktioner (højtuddannede ansatte eller selvstændige med stor indtjening) om den legitimt distingverede livsstil, eller skiftet fra 
'70er-marxisme til '80er-postmodernisme, -poststrukturalisme etc. inden for det litteraturvidenskabelige felt i Danmark (den tilsyneladende omvendte udvikling i USA - fra dekonstruktion til political correctness - understreger relativiteten i denne udvikling). Avantgarde-logikken i kunsten kan også beskrives som en distinktionsproces.

Der eksisterer altså i reglen flere distinktionsparadigmer i et felt, homologt til det sociale rum, hvor der er en overordnet konkurrence mellem de kulturelt og de $\emptyset$ konomisk dominerende om kulturens eller $\emptyset$ konomiens dominans som samfundsmæssig grundværdi, eller en mere specifik konkurrence om, hvad der er legitim kultur (f.eks. i modsætningen mellem avantgarde- og boulevardteater, som Bourdieu analyserer s.258-67). I en generaliseret form kunne man tale om to typiske, konkurrerende disitnktionsparadigmer: det ene bygger på den suveræne beherskelse og anvendelse af feltets koder; det andet ligeledes på en beherskelse af koden suppleret med en symbolsk overskridelse af den (en limotrof position kalder Bourdieu den i forbindelse med Derrida (note 35, s.582)). Eksempelvis i forholdet mellem seriøs fagfilosofi (forpligtet på sandhed og logisk stringens mv.) og en nietzscheansk (derridask, '70er-barthesk) position, der overskrider det filosofiske felt ved at pege på dets spilkarakter, men alligevel forbliver inden for feltet; denne symbolske overskridelse er muligvis den mest præcise betydning af det ret vage begreb subversion, som man også finder hos Bataille. Begge positioner konkurrerer om at påtvinge den anden den legitime definition af filosofisk distinktion, f.eks. som hos Nietzsche, der vil opstille en rangordning (d.v.s. en dominansrelation) af filosofferne $\gg$ utfra den måten de kan le på - helt op til dem som har evne til en gyllen latter $\ll,{ }^{9}$ hvor latteren som i Baudelaires essay De l'essence $d u$ rire fungerer som en (selv-)distancering fra agentens investering i feltet, og hvor det gyldne er et distinktionstegn (guldet er vel et af de historisk set mest stabile tegn på høj $\emptyset$ konomisk kapital, anvendeligt som metafor for andre slags høj kapital). Begge positioner kan argumentere for en hævdelse af deres egen distinktion (»Hvordan kan de forkaste den filosofiske kode, når de vil forblive inden for feltet?« - Hvordan kan de dog tage denne leg så alvorligt?«), og ultimativt kan konkurrencen føre til oprettelsen af to forskellige felter, f.eks. svarende til konkurrencen mellem filosofi og litteraturvidenskab. En tilsvarende konkurrence mellem de to typiske distinktionsparadigmer kan observeres inden for andre felter som mad, tøj, vin etc., ofte konkretiseret som konkurrencen mellem en»regel«æstetetik og en»lyst«æstetik, hvis brud på koden (som hos vinkenderen, der bestiller en vin, fordi etiketten er pæn) naturligvis må forudsætte et indgående og anerkendt kendskab til koden.

Udover distinktion er smag et vigtigt begreb i La distinction. Bourdieu definerer smag som det system af perceptions- og vurderingsskemaer, som be- 
tinges af en given habitus, der som tidligere nævnt er internaliseringen af de objektive livsbetingelser. Smag er altså evnen til at skelne og vælge mellem det, man kan lide og ikke kan lide, evnen til at værdsætte det og evnen til at vurdere andres valg. Smagen er ofte ubevidst, for så vidt som agenten sjældent foretager koblingen til dens betingethed af sociologiske faktorer, og den fremtræder derfor som naturlig. Deraf den substantialistiske tænkning: substans forstået som værdiladede egenskaber (god vin, kunstnerisk værdi, luksus etc.) findes kun sålænge man befinder sig inden for et felt, d.v.s. i en interesseret $\mathrm{og}$ betinget position (det gør man jo til gengæld mestendels også). Bourdieu vil naturligvis ikke dermed benægte, at der findes objektivt målelige egenskaber ved vin (kemisk sammensætning), i litteratur (grammatisk og, allerede sværere målelig, strukturel kompleksitet) og ved luksusforbrugsgoder (kvalitet af forarbejdning og materialer) o.s.v.; det er den værdi, som disse objektive egenskaber tillægges, der er relativ. Og denne værdi konstitueres i tingens sociale brug og afhænger derfor af måden, den tilegnes eller anvendes på. Relativismen kan illustreres af den vidt forskellige værdi, som udsagnet »jeg sætter mest pris på de gratis glæder i livet« har, alt efter om udsigeren har lav eller høj økonomisk kapital: i det første tilfælde er der blot tale om at gøre dyd af den $\emptyset$ konomiske nødvendighed, altså en internalisering af den $\emptyset$ konomiske tvang, $\mathbf{i}$ det andet tilfælde kan agenten høste en distinktionsprofit ved at foretage en symbolsk forkastelse af den $\varnothing$ konomisk betingede distinktionskode. Tilsvarende har udsagnet »jeg holder meget af B-film« en forskellig værdi efter agentens kulturelle kapital (omend allerede brugen af ordet B-film, henvisende til en hierarkisk klassifikation, indicerer en høj kulturel kapital).

Med talrige statistikker demonstrerer Bourdieu - ganske overbevisende - at de sociale klassers smag udviser sammenhæng inden for vidt forskellige smagsfelter, d.v.s. at kulturforbruget (i bred forstand) ikke kombineres vilkårligt, men samler sig i typer af livsstil. Til det sociale rum svarer derfor et livsstilsrum (espace des styles de vie), der varierer med stigende kapitalmængde fra vulgær over prætentiøs til distingveret smag (i en socialt ladet terminologi), mens kapitalstrukturen betinger en skala med kunstnerisk og»borgerlig« (luksus-)smag som yderpunkter.

Princippet for mange af de kulturprodukter, der accepteres af den distingverede og specielt den borgeligt-distingverede smag, er ifølge Bourdieu en »dénégation du monde social «, en fornægtelse af den sociale verden. Det betyder, at kulturproduktet ved at blive et mål i sig selv løsriver sig fra dets sammenhæng med klassespecifikke produktions- og forbrugsfelter, - hvilket i sig selv er et klassespecifikt træk. Hvis man f.eks. i Guide Michelin analyserer forholdet mellem gastronomisk kvalitet (målt ved skalen 0-3 stjerner) og social appel (målt ved skalen 1-5 gafler, der betegner »le confort«, restaurantens udstyr 
og indretning, en forholdsvis sikker indikation af social status) på det parisiske restaurant-felt, viser der sig en klar korrelation mellem kvalitet (som sædvanligvis tænkes uafhængigt af sociologiske faktorer) og social status. ${ }^{10}$ Pointen i denne korrelation er imidlertid ikke, at gastronomisk kvalitet alene afhænger af, hvem der spiser maden; selv om min smag, d.v.s. perceptionsevne, naturligvis er formet af bl.a. Guide Michelin, vil jeg mene, at gastronomisk kvalitet inden for et specifikt felt (her det franske køkken) er nogenlunde objektivt perceptibel (d.v.s. findes), og at stjernetildelingen således er nogenlunde rimelig. Når der er denne homologi mellem to hierarkisk organiserede felter, mellem produktionsfelt og forbrugsfelt, mellem maden og gæsterne, er det snarere fordi perceptionen og værdsættelsen af (d.v.s. smagen for) den højere og højeste gastronomi dels fordrer økonomisk kapital (den bedste mad er dyr), dels en specifik gastronomisk kapital, hvis erhvervelse igen fordrer økonomisk kapital, for slet ikke at tale om en vis social kapital (at vide hvordan man skal gerere sig på »de fine steder « - eksempelvis i forhold til hummergafler, der ofte bruges (også ironisk) som indikator af social kapital). Den gensidige $\emptyset$ konomiske determination $\mathrm{i}$ forholdet mellem produktionsfelt og forbrugsfelt har en selvforstærkende virkning, således at dyre råvarer opfattes som inkarnationen af gastronomisk kvalitet - hummer, foie gras, kaviar, trøfler m.v. - selv om produktionsfeltets distinktionskode snarere angår kokkemæssig kunnen og opfindsomhed. Hvilket altsammen ikke forhindrer, at feltet også er åbent for afvigende agenter som undertegnede. Et andet eksempel: inden for kunstarterne danner Bourdieu et hierarki efter deres grad af fornægtelse af den sociale verden. Musikken, specielt den»rene« uden tekst, har den højeste grad og dernæst kommer poesien. Hvis man ser på nogle digtere af den højeste distinktion og legitimitet - jeg vælger Mallarmé, Rilke og Yves Bonnefoy (tit betegnet som en af de største digtere i efterkrigstidens Frankrig) - vil man se, at de ofte udtrykker sig i et begrænset vokabular (i reglen af substantiver), der som tematisk koncentrerede nøgleord bruges igen og igen: ${ }^{11}$ p.g.a. disse nøgleords abstrakte og generelle karakter, der løsriver digtet fra praktiske sproglige sammenhænge, tenderer digtet mod at være en fornægtelse af den sociale verden; jeg finder det selv nærmest upassende, at Rilke i den 19. sonet i 2. del af Die Sonette an Orpheus nævner banker, penge og forretninger, så hvis læseren spørger, hvad den sociale verden skulle i digte, så er det just pointen. Lad mig endnu engang understrege, at der i dette ikke ligger nogen dom, men blot en konstatering.

Læsere med høj filosofisk kapital vil måske i al denne teoretiske gymnastik finde tautologier eller cirkelslutninger, og det kan der muligvis også være grund til. Med risiko for at blive involveret i en ørkesløs debat om hvorvidt teorien eller empirien bør dominere på dette felt, må jeg imidlertid på Bour- 
dieus vegne sige, at mange forhold i den sociale verden er tautologiske. Her kommer Bourdieus begreb om symbolsk kapital ind. Symbolsk kapital er det, som den dominerende i en dominansrelation har, for så vidt som de dominerede anerkender den. Den kan derfor meget vel være en fiktion, som bygger på bluff (f.eks. anerkendelse af en henkastet bemærkning, der antages at antyde en omfattende viden). På samme måde kan en agent forsøge at etablere en dominansrelation ved at agere som autoritet, og hvis feltets andre agenter anerkender autoriteten, er den en autoritet og dominansrelationen etableret. Sådanne forhold er mere eller mindre tautologiske, ligesom distinktion og forholdet mellem habitus og felt:

»De dominerende, som på sin vis er født ind i en positivt distingveret position, fremtræder som distingverede, fordi deres habitus som en socialt konstitueret natur er umiddelbart tilpasset til spillets immanente krav, og fordi de således kan affirmere deres forskel uden at have behov for at ville det, d.v.s. med den naturlighed som er kendetegnet for den såkaldte »naturlige« distinktion: de behøver blot at være, hvad de er, for at være hvad, de bør være. [...] Habitusen står i et veritabelt ontologisk komplicitetsforhold til den sociale verden, som den er produkt af ... ${ }^{12}$

Samme komplicitetsforhold er der mellem det reelle og dets symbolske repræsentation, mellem teori og praksis. De symbolske repræsentationer, f.eks. klasseinddelingen af det sociale, har så at sige en reel autonomi, der virker tilbage på det reelle, således at klassificeringen også bidrager til at skabe klasser, fordi den fungerer som handlingsorienterende fortolkninger af reelle strukturer (man kan f.eks. tænke på den traditionelle arbejdersolidaritet, som kan ses som en effekt af teorien om, at der findes en arbejderklasse). Og det tautologiske kommer altså simpelthen af, at det er de dominerende, som fastlægger dominanskriterierne (d.v.s. koden for legitim distinktion), eller sagt på en supertautologisk måde: de privilegerede er privilegerede, fordi det er de privilegeredes privilegium at hævde, at det er et privilegium at have privilegier. Hvilket som tidligere nævnt ikke udelukker, at et givet privilegiums privilegium ustandseligt udfordres og hyppigt forkastes - en evindelig bevægelse, i hvilken dominansrelationerne som abstrakt struktur netop bevares.

\section{Uddannelse, kultur, historie}

Et mål for anvendeligheden af Bourdieus teorier må være deres evne til at tage højde for de ændringer i kultur- og samfundsbilledet, der har fundet sted i ef- 
terkrigstiden. Som allerede nævnt er modsætningen mellem kulturel og økonomisk kapital i den dominerende klasse tendentielt afløst af modsætningen mellem to forskellige slags uddannelseskapital: de humanistiske på den ene side og de $\varnothing$ konomiske og administrative på den anden side, som ligger til grund for modsætningen mellem intellektuelle og økonomiens og administrationens ledere, hvor sidstnævnte - som noget nyt - har fået »følelsen af at have en intellektuel ret til autoritet over samfundets adfærd« (s.361). Denne ændring er kun ét udtryk for nogle omfattende udviklinger.

En af de vigtigste årsager til ændringer i det sociale og dermed også i kulturen er ifølge Bourdieu ændringerne i uddannelsessystemet, som beskrives i afsnittet »Les stratégies de reconversion« (s.145-185).

For at opretholde deres relative status må alle klasser reproducere og eventuelt $\emptyset$ ge deres kapitalmængde. For nogle klasser er udviklingen i efterkrigstiden imidlertid forløbet sådan, at de har måttet anlægge strategier for en rekonversion af deres kapitalstruktur: således har klasser med lav uddannelse og høj $\emptyset$ konomisk kapital søgt at reproducere deres kapitalmængde ved en intensivering af uddannelse - Bourdieu nævner børn af håndværkere, forretningsdrivende og traditionelle arbejdsgivere. Det tvinger imidlertid de klasser, hvis reproduktion traditionelt er sket $\mathrm{i}$ uddannelsessystemet, til ligeledes at intensivere brugen af uddannelsessystemet, hvilket fører til en overproduktion af uddannede og dermed til en devaluering af uddannelse generelt, fordi arbejdsmarkedet ikke (altid) har udviklet sig i samme takt. Eftersom en agents chance for succes i uddannelsessystemet statistisk set afhænger af den sociale herkomst, medfører denne devaluering et antal effekter: for det første er de største tabere i denne øgede konkurrence dem, som er mindst uddannede, hvoraf en del altså vil være børn af lavtuddannede. For det andet medfører det ændrede forhold mellem en given uddannelse og det tilsvarende arbejde en strukturelt betinget, men personligt følt desillusionering i nyere ungdomsgenerationer, der ifølge Bourdieu er baggrunden for modkulturer (hippier, punk, etc.), forstået som forkastelse af dominerende normer om livsforl $\emptyset$ b. Den mere snigende udelukkelse fra samfundslivet, som skabes af, at det er muligt at få en uddannelse, men vanskeligt at få et tilsvarende arbejde, giver de udelukkede en ustabilitet $\mathrm{i}$ deres sociale identitet, en uendelig udsættelse af fikseringen $\mathrm{i}$ en klar samfundsmæssig position. For det tredje vil agenter uden større succes i uddannelsessystemet, men med nogen eller megen social kapital ofte søge mod nye, d.v.s. åbne og socialt udefinerede, erhverv, eksempelvis i medierne, rådgivning, nye butiksbrancher, etc., hvor den sociale kapital kan finde anvendelse. Bourdieu betegner disse udefinerbare grupper som $\gg$ det nye småborgerskab «, hvis værdier ofte ligner eller prætenderer at ligne dem, som man finder hos »det nye borgerskab «, de højtuddannede ledere af økonomi og administra- 
tion.

Resultatet af den $\emptyset$ gede uddannelsesgrad, som medfører en devaluering af værdien af uddannelse og dermed også en stigende konkurrence i uddannelsessystemet og på arbejdsmarkedet, hvor klasser med de bedste forudsætninger klarer sig bedst, er altså totredjedelssamfundet, som man kender det i dag: et samfund, der er givet ved en skærpet konkurrence mellem de grupper, som vil spille spillet, og en relegering af dem, som ikke kan eller vil spille spillet, til bistandshjælp, arbejdsløshed eller tilfældige småjobs.

Eftersom kulturforbruget afhænger af uddannelsesniveauet, medfører den stigende uddannelsesgrad et stigende kulturforbrug. To forhold indvirker imidlertid på dette kulturforbrugs art: for det første medfører den bredere sociale rekruttering blandt de uddannede sandsynligvis en lavere kulturel kapital for et givent uddannelsesniveau end $\mathrm{i}$ tidligere tilstande (før 2 . verdenskrig). For det andet er finkulturen defineret ved sin relative sjældenhed (eller utilgængelighed for de fleste), og et givent kulturprodukt (f.eks. impressionismen) kan derfor risikere at tabe sin finkulturelle status, hvis det bliver for udbredt (allehånde modreaktioner kan derfor opfindes, hvis man vil bevare distinktionen: i klassisk musik kan man forskyde interessen fra musikstykket til musikeren, i forbindelse med impressionismen kan man forskyde interessen til f.eks. Monets sene værker, etc.). Omvendt kan den faldende popularitet af en kulturel aktivitet gøre den mere distingveret, som det er tilfældet med biografbes $\emptyset \mathrm{g}$ (fra 1964 til 1987 faldt billetsalget i Danmark til 1/3), der er ved at blive synonymt med kvalitet. Disse to forhold tilsammen betyder, at væksten i kulturforbruget er en vækst i den relativt mindre distingverede, mere populære kultur, og det medfører muligvis en mindskelse af den relative betydning af den mest distingverede kultur, så meget mere som denne kultur er stadigt mere domineret, fordi den dominerende fraktion af den dominerende klasse i kraft af deres højere uddannelsesgrad får mere kulturel autoritet til at forkaste den.

Definitionen af modkulturer, subkulturer eller alternativkulturer er, at de er dannet i en relation til den dominerende kultur, i første omgang ikke så meget som konkurrerende kulturer, men snarere som tilflugtssted for de agenter, som ikke behersker den dominerende kulturs koder (f.eks. alternativ medicin i forhold til den dominerende medicin), selv om også modkulturer fordrer en vis kulturel kapital. Punken er et godt eksempel på en nærmest bogstavelig inskription af dominansrelationer på kroppen, der kan være selvdestruktiv, hvis man tager den alvorligt, og frigørende, hvis man let distanceret betragter den som en slags meget sort humor - hvilket netop forudsætter en vis kulturel kapital. En mulig udvikling for agenterne på et subkulturelt felt kunne derfor være, at de agenter, der har den laveste kulturelle kapital, fortabes (som de aldrende og opløste punkere, der kan observeres i Berlins Kreuzberg-kvarter i 
dag), mens de agenter, der har mest kulturel kapital, kan ende som legitime kunstnere. Modkulturer er således ofte ambivalente i deres stilling til den legitime kultur, som de definerer sig i forhold til.

Denne beskrivelse af nogle ændringer i samfunds- og kulturbilledet - hvor forsimplet og ufuldstændig den end er - kan tjene som eksempel på Bourdieus relationelle måde at tænke historie på. På den ene side tænker han de historiske strukturer og udviklinger i så abstrakte termer (dominansrelationer, felter etc.), at de forekommer at være ens nu og for 2000 år siden, på den anden side er hans analyser meget historisk konkrete og specifikke. Så selv om det kan se ud, som om slaveri, hoveri og lønarbejde er ét fedt, fordi de udtrykker homologe dominansrelationer, så vil en redegørelse for, hvordan man kommer fra den ene type til den anden, være en uhyrligt kompliceret historie om interaktionen mellem forskellige felter (teknologiske, sociale, religiøse, ideologiske o.s.v.). Pointen i denne på én gang meget abstrakte og meget konkrete historieopfattelse er, at de historiske ændringer har tendens til at reproducere de samme grundlæggende ulighedsstrukturer på nye måder (man kan f.eks. tænke på de sortes situation før og efter slaveriets ophævelse i USA). En bourdieusk historie er altså en kontinuert interaktion og social konkurrence, der under forskellige synsvinkler kan udskrystalliseres i tilstande som stændersamfund/ kapitalistisk samfund eller landbrugssamfund/industrisamfund - en anden historie, altså, end de historier om bureakratisering, rationalisering og modernisering, som Bourdieu mener »giver megen social profit til deres forfattere og liden videnskabelig profit $\ll^{13}$

\section{Videnskabelighed, refleksivitet og frigørelse}

På trods af min rigeligt abstrakte fremstilling skulle det vel være tydeligt, at Bourdieu besidder en høj grad af akademisk og kulturel distinktion. Teorien og sproget er kompliceret, empirien nærmest altomfattende, og han synes at være lige godt hjemme i filosofi, videnskabsteori, sociologi, litteratur og kunst. Denne $\mathbf{h} \varnothing j$ e distinktion truer imidlertid med at gøre refleksiviteten til en performativ selvmodsigelse. For som han selv siger, er klassifikation en måde at udøve magt på, en måde at etablere en dominansrelation på, og objektiveringen af det sociale tæt på at være manipulation; at han også objektiverer sig selv, er i den sammenhæng kun en måde at afvæbne de objektiveredes kritik på. Han spiller så at sige et spil, som han - jvf. de fem stadier i læsningen - er sikker på at vinde. I slutningen af Leçon sur la leçon siger han: 
»Det paradoksale foretagende, der består i at bruge en autoritetsposition til at sige med autoritet, hvad det er at sige noget med autoritet, til at give en lektion, men en lektion om frihed fra alle lektioner, ville være simpel inkonsekvens, for ikke at sige selvdestruktion, hvis ikke selve ambitionen om at lave en videnskab om tro forudsatte en tro på videnskaben. I hvert fald er intet mindre kynisk, mindre machiavellisk end disse paradoksale udsagn, som udsiger eller bekendtgør selve princippet for den magt, de udøver. $\ll^{14}$

Selv om jeg gerne tror på Bourdieus bedste intentioner, er det ikke til at komme udenom, at refleksiviteten også fungerer som et våben i det akademiske spil, og at en uendelig regres derfor truer: det ser ud som om Bourdieu v.h.a. objektiveringen af dominansrelationerne i de sociale spil søger at opnå en uangribelig dominans på det intellektuelle felt. Mod det har Bourdieu den videnskabelige sandhed at sætte ind. Den videnskabelige sandhed er det udsagn, som ikke lader sig bestride uden ved bedre videnskab, og dens gyldighed afficeres ikke af videnskabsmandens interesse for at distingvere sig på sit felt: »Hvis sociologen når til at producere en smule sandhed, så er det ikke på trods $a f$, at han har interesse $\mathrm{i}$ at producere denne sandhed, men fordi han har interesse i den «. ${ }^{15}$ Spørgsmålet om Bourdieus videnskabelighed er altså det springende punkt. Umiddelbart forekommer hans omgang med statistik og hans uhyrlige præcision meget tilforladelig, omend jeg ikke på det område har megen videnskabelig kompetence; det er jo ikke just det, man har dyrket i det sidste tiårs litteraturvidenskab. Men man kan måske sige, at Bourdieu forsøger at opløse modsætningen mellem en nietzscheansk position, hvor sandheden er fiktion og vilje til magt, og en videnskabelig position, der bygger på troen på sandhed, fordi den refleksive dimension ikke modsiger, men tværtimod bekræfter hans udsagn: Bourdieu har en klar interesse i og vilje til dominans inden for det sociologiske felt, men denne dominans kan kun nåes ved at spille sandhedens spil (fiktion), og den kan derfor ikke kritiseres fra den position, der kan objektiveres som den, der objektiverer spillet som spil uden at medreflektere sin egen tvetydige stilling til spillet.

Som videnskab om det sociale har sociologien grænser, omend det kan være svært at definere dem. Den specifikke logik ved specifikke felter (f.eks. det litterære) kræver specifikke analyser, der ikke hører til sociologiens område, men som sociologien kan inddrage $i$ analyser af f.eks. dominansrelationerne $i$ det litterære felt (eller omvendt: litteraten kan inddrage sociologien). Man kan altså ikke analysere tekster med Bourdieus sociologi, i hvert fald kun de sociologiske aspekter af de fiktive universer (hvilket da også er oplagt i f.eks. Stendhals Le rouge et le noir eller hos Proust, der i øvrigt er en af Bourdieus 
hyppige referencer). Men man kan bruge Bourdieus sociologi til at analysere de institutionelle betingelser for produktion, brug, vurdering og fortolkning af litteratur ${ }^{16}$ eller til at analysere forholdet mellem feltet for litterær produktion og feltet for litterær brug (det ville være en slags radikaliseret jaussk receptionshistorie, som f.eks. kunne forklare den sollerske skrifttematiks begrænsede og stadig mindre succes: brugsfeltet nægtede stort set (med undtagelse af bl.a. Barthes) at anerkende skrifttematikkens fordring på litterær distinktion). Bourdieus højt abstrakte begreber har derfor deres styrke i, at de kan bruges til at tænke et felt i dets konkrete og historiske specificitet i forhold til det sociologisk konkrete og på niveauer af vidt varierende størrelse.

Vanskeligheden ved sådanne analyser er imidlertid, at de fordrer en omfattende enten faktuel eller intuitiv viden om det specifikke felt, helst begge dele. Men er den betingelse opfyldt, er Bourdieus kulturanalytiske anvendelsesmuligheder nærmest ubegrænsede - som mine eksempler forhåbentlig har illustreret.

Sluttelig er det måske værd at nævne, hvori Bourdieus interesse - udover interessen $i$ akademisk distinktion - består. Han opfatter produktionen af videnskabelig sandhed om det sociale som et led i en frigørelsesproces: den eneste frihed man kan nå til er, siger han, at kende sine objektive determinationer, d.v.s. friheden fra friheden som illusion. Ved at have en viden (connaissance) om de dominansrelationer, man er indspundet $i$, kan man komme fri af den miskendelse (méconnaissance) af dem, som fører til en ukritisk anerkendelse (reconaissance) af dem. Også i dette synspunkt er der en vanskelighed, siden Bourdieus viden er formuleret $i$ et sprog, der er utilgængeligt for alle andre end akademikere, bl.a. fordi de også er de eneste, der har tid til at beskæftige sig med så besværlige tekster: skole kommer af schole, der både betyder fri tid og studium, som Bourdieu ofte gør opmærksom på. Og hvis man som akademiker forklarer de dominerede, at de er dominerede af de og de grunde, habitus og felt og kapital og hele møllen, kan man være temmelig sikker på, at også de vil opfatte det som et forsøg på dominans. Dette frigørelsesaspekt, dette beskedne oprør mod dominans, er dog ikke et, som Bourdieu bruger megen plads på - bl.a. for at holde den videnskabelige beskrivelse fri af det politisk normative - men det hører med som en del af hans interesse.

Selv om mange emner er forblevet ubehandlede - f.eks. Bourdieus kritik af Kants æstetik, og hans afsnit om politik og demokrati - har denne introduktion forhåbentligt gjort det klart, at det i høj grad er muligt - og endda nyttigt og afklarende for mange spørgsmål - at tænke forholdet mellem kultur og klasse i dag. At Bourdieu kan kritiseres på forskellige punkter er vel også klart, selv om det ikke har været min intention at gøre dét - bl.a. fordi jeg ikke føler mig kompetent til det, hverken filosofisk eller sociologisk. I hvert fald vil jeg håbe, 
at denne introduktion kan lokke nogle læsere, kritiske og interesserede, til at læse Bourdieu - også selv om det vil mindske den relative værdi af min Bourdieu-kapital.

\section{Noter}

1. Paris 1979. Engelsk oversættelse: Distinction. A Social Critique of the Jugdement of Taste, Cambridge, Mass. 1984, paperbackudgave London 1986. Referencer gives i teksten, og alle oversættelser er mine egne. Kursiveringer i citater er derimod Bourdieus.

2. Dele af Choses dites er oversat til engelsk med titlen In Other Words , 1990, der også rummer en oversættelse af Leçon sur la leçon og en bibliografi over Bourdieus skrifter 1958-88.

3. Leçon sur la leçon, s. 8.

4. Dog bryder han sig ikke, så vidt jeg kan se, om den amerikanske funktionalistiske sociologi, f.eks. Talcott Parsons (se Choses dites, s. 50-51), og dermed antagelig heller ikke om Niklas Luhmann, hvis begreber ellers godt kunne ligne Bourdiues noget - for en overfladisk betragtning, som den jeg er i stand til at anlægge. I hvert fald er der ingen referencer til Luhmann i de værker af Bourdieu, jeg har læst.

5. Choses dites, s. 41.

6. Choses dites, s. 150.

7. Bourdieu forklarer ikke, hvordan man adderer kulturel og økonomisk kapital: svarer en magistergrad eller kendskabet til Shakespeares samlede værker til en vis indkomst eller formue? Kan der overhovedet etableres en meningsfuld ækvivalens mellem de to størrelser? Til en vis grad synes det faktisk at være tilfældet; man kan f.eks. tænke på en kunstner, der i sin egenskab af kunstner (d.v.s. for vedkommendes kulturelle kapital) færdes i kredse med høj kapital af andre slags (f.eks. Proust $i$ de adelige kredse). Eftersom uddannelsessystemet har tendens til at reproducere forskellene i social herkomst, vil der i de dominerende kredse inden for kultur og kapital også kunne være sammenfald i baggrund, der tillader en social ækvivalens på trods af de to felters relative autonomi.

8. Choses dites, s. 130.

9. Freiedrich Nietzsche: Hinsides godt og ondt, København 1990, s. 249.

10. De trestjernede restauranter har i gennemsnit 4,6 gafler, de tostjernede i gennemsnit 3,9 , mens de enstjernede har 2,7 og restauranter uden stjerner 1,9 (Guide Michelin, 1989).

11. Nogle eksempler hos Mallarmé: blanc, écume, froid, pli, astre etc. Hos Rilke: Baum, Raum, Krug, Erde, Herz, Sein etc. Hos Bonnefoy: arbre, maison, flamme, houille, verbe etc.

12. Choses dites, s. 21-22.

13. Choses dites, s. 56.

14. Leçon sur la leçon, s. 56.

15. Questions de sociologie, s. 23.

16. Det behøver man naturligvis ikke at vente på Bourdieu for at gøre; se eksempelvis Frank Kermodes essays »Can We Say Anything We Like? « og »Institutioal Control of Interpretation«, in: Essays on Fiction, London 1983. 